AperTO - Archivio Istituzionale Open Access dell'Università di Torino

\title{
IMMUNOPHENOTYPIC RESPONSE AFTER ALLOGRAFTING IN MULTIPLE MYELOMA
}

\section{This is the author's manuscript}

Original Citation:

Availability:

This version is available http://hdl.handle.net/2318/149790

since

Terms of use:

Open Access

Anyone can freely access the full text of works made available as "Open Access". Works made available under a Creative Commons license can be used according to the terms and conditions of said license. Use of all other works requires consent of the right holder (author or publisher) if not exempted from copyright protection by the applicable law. 


\section{IMMUNOPHENOTYPIC RESPONSE AFTER ALLOGRAFTING IN MULTIPLE MYELOMA}

Luisa Giaccone, Lucia Brunello, Roberto Passera, Moreno Festuccia, Milena Gilestro, Enrico Maffini, Federica Ferrando, Federica Testa, Mario Boccadoro, Paola Omede', Benedetto Bruno.

Background: Recent studies suggest that immunophenotypic remission (IR) may be a relevant prognostic factor in patients with multiple myeloma (MM). However, data on this role after allografting are lacking. Aim: To evaluate the impact of IR and compare it to conventional complete remission (CR) in myeloma patients treated with an allograft. Methods: Sixty-six consecutive patients, median age 54 years (35-66), who underwent an allograft between January 2000 and December 2011 with a follow-up of at least 3 months were included. Disease response was evaluated by serum and urine electrophoresis, and bone marrow aspirate at 3, 6, 12, 18, 24 months after transplant and yearly thereafter. Skeletal survey or MRI were performed yearly or as clinically indicated (overt relapse or complaints of bone pain). Bone marrow aspirates had to contain at least 13000 cells/ $\mu \mathrm{L}$ for flow cytometry studies and IR was defined as absence of monoclonal plasmacells detected by 4 or 6-colour staining with the following antibodies: CD38, CD138, CD56, CD19, CD45, cyKappa, cyLambda. CR was defined according to standard criteria (Leukemia. 2006;20:1467-73). Results: Conditioning regimen was non-myeloablative 2Gy TBIbased in 55 patients, reduced intensity (fludarabine-melphalan-based) in 10 and myeloablative in 1 patient. Post-grafting immunosuppression consisted of cyclosporine with mycophenolate mofetil or methotrexate. Donors were HLA identical siblings in 58 patients and unrelated in 8 . Only 1 patient received bone marrow as source of stem cells. Thirty-five/66 (53\%) received the allograft as part of the first line treatment, whereas the others $(31 / 66,(47 \%)$ were transplanted after disease relapse. Among patients surviving at least 3 months, treatment related mortality was $10.6 \%$ at 3 years. After a median follow-up of 69 months (range 19-147), the incidence of acute and chronic graft-versushost disease was $45.6 \%$ and $49.3 \%$, without significant difference between responsive and nonresponsive patients. At follow-up, 24 patients achieved CR and IR (CR/IR), 22 achieved IR but not CR because of persistence of urine/serum M-component (noCR/IR), and 20 did not achieve either CR or IR (noCR/noIR). Interestingly, none achieved CR without IR. Median overall (OS) and event-free survivals (EFS) were not reached and 59 months in the CR/IR group, 77 and 15 months in the noCR/IR, and 30 and 5 months in the noCR/noIR respectively $(\mathrm{p}<0.001$ for both OS and EFS). Being in the CR/IR group was the only significant predictor for prolonged OS and EFS $(\mathrm{p}<0.001)$. Of note, the cumulative incidence of extramedullary disease at first relapse after the allograft was $4.4 \%$ in the CR/IR, $31.8 \%$ in the noCR/IR and $15.0 \%$ in the noCR/noIR groups respectively $(\mathrm{p}<0.001)$. Receiving the allograft as first line therapy or later during the disease course did not significantly impact on OS and EFS. Conclusions: The achievement of IR showed a significant impact on clinical outcomes including patients who did not clear the M-component. Discrepancies between IR and CR, observed in the noCR/IR group (some 30\% of our patient cohort) along with a higher incidence of extramedullary relapse, suggest that myeloma cells may escape immune control outside the bone marrow. In this group, imaging studies such as positron emission tomography may be indicated to allow detection of early relapse. 